\title{
Anna Rogozińska-Pawełczyk*
}

\section{USEFULNESS OF THE PSYCHOLOGICAL CONTRACT CONCEPT: THE DEFINITION AND CONCEPTUAL CONSIDERATIONS}

\begin{abstract}
This paper focuses on the review, analysis and synthesis of literature on the psychological contract. The main purpose of the synthesis in the extensive literature review is to delineate the scope in which interpersonal relations and employment relations can be created in an organisation. The article is part of broader theoretical considerations aimed at exploring and explicating the foundations of the psychological contract as a concept, and at conducting a chronological analysis of its development. Tracing this evolution provides a basis for exploring the significance of psychological contract as a regulator of employment relationships between employers and employees. The analysis and synthesis of the findings constitutes a contribution to efforts aimed at identifying gaps in existing reflection, and indicates implications for future research. To date, no comprehensive attempt has been made to present a systematic chronology and to capture changes in the terminology of psychological contract over the years.
\end{abstract}

Keywords: psychological contract, employee-employer relations, mutual expectations and obligations.

\section{Introduction}

Human lives are regulated by various contracts that are necessary to establish lasting, harmonious relations between the employee and the organisation. Many researchers indicate that there is an unwritten psychological contract that the employee and the employer enter into when signing the employment contract (cf. Rousseau 1995; Briner, Conway 2005; Kelley-Patterson, George 2002).

A psychological contract is defined as an idiosyncratic set of mutual promises, expectations and commitments between an employee and an organisation (Rousseau 1989). The idea behind the psychological contract is to define the dynamic relations between the employee and the employer within the organisational

* Prof. of the University of Łódź, PhD, Department of Labour and Social Policy, Faculty of Economics and Sociology, University of Łódź, ul. Rewolucji 1905 r. 37, 90-214 Łódź, e-mail: anna.rogozinska@uni.lodz.pl 
environment (Pate 2006) and to shape and implement human resources policy within the changing mutual expectations, commitments and promises (Coyle-Shapiro et al. 2004).

The theory of psychological contract is an important and revealing research perspective which relates to the combination of the interests of the employer with the diverse interests and expectations of employees in adapting to the special characteristics of their processes. The advantages of this perspective are primarily related to three aspects. Firstly, it focuses on mutual obligations between the parties to the contract, but the analysis can be carried out from the perspective of any part of the exchange. Secondly, the importance of a psychological contract in the organisation is highlighted through the empowerment of the employees and the role of the management and direct superiors, thus increasing flexibility in adapting to changing objectives or tasks. Another advantage is the focus on the individual perception of expectations and psychological obligations or, more specifically, behavioural obligations, i.e. those different from legal obligations. The fourth argument for the usefulness of the psychological contract concept in research lies in its complexity. The concept invokes a number of specific approaches and tools in human resources management, which in practice are often applied in a selective or fragmentary manner, without considering the strategic aspect, which takes into account the special nature of business processes and related requirements, as well as the welfare of employees in the organisation (Rogozińska-Pawełczyk 2011; 2016). Moreover, the psychological contract consolidates many well-known concepts in the field of management science, and the sociology and psychology of organisations, by localising them and indicating interdependencies.

The psychological contract has become an important theory, supporting the understanding of human nature and the dynamics of the employment relationship (Zagenczyk et al. 2009). However, the phenomenon of changes within the psychological contract itself has not yet been fully explored, which means that it is important to continue this exploration. Accordingly, the aim of this paper is to construct a comprehensive framework for understanding the internal architecture of the psychological contract and its shaping mechanisms within the framework of terminological analysis. To this end, we provide a critical review of the available literature on the psychological contract, which shapes the employment relationship between the employee and the employer. The main advantage of this study is its informative role regarding the concept of psychological contract (which, as yet, is not very popular in Polish-language literature).

\section{The methodology of research exploration}

In order to review the literature in the area of psychological contract, the desk research method was used to collect and analyse the existing and available data. The desk research involved a review of online databases (Scopus, JSTOR, Eb- 
scoChost, Wiley Online Library, Sage, Emerald, and EBSCO) together with thematic areas related to the science of organisation and management. The keywords used in the search of this category were: labour relations, interpersonal relations, employment relations, psychological contract, expectations and obligations, and human resources management versus psychological contract. Information was collected using the databases available in the electronic library of the University of Łódź. Given that there was no access to the latest issues of journals and scientific periodicals or that the currently subscribed collections were unavailable, the analysis ends at December 2019.

In accordance with the aim of this article, a comprehensive attempt was made to systematise and capture the changes in the terminology of the psychological contract that have occurred over the years. The focus was on the origin, emergence and development of the psychological contract concept. The set of definitions often points to divergent views on various components of the contract. The revealed differences of views concern such components of the contract as: beliefs, expectations and commitments, and the nature of the psychological contract.

The concept of a contract is not new, since "social contract" occupies a prominent position in political economics and political philosophy (cf. Hobbes 2005; Locke 2002). The psychological contract has received considerable attention in both academic and practical discourse over the last twenty-five years.

\section{Early definitions of psychological contract}

The first attempts to understand the nature of mutual relations at work go back to Barnard's theory of equilibrium (1938), which suggests that employee participation at work is dependent on their receiving suitable benefits from the organisation. March and Simon developed this theory in their incentive-contribution model (1958), providing a more detailed description of the means being exchanged. These researchers argued that the continued contribution and effort of employees depends on their perception of the incentives offered by the organisation to employees for their work.

Menninger (1958) is commonly regarded as a pioneer of the idea of psychological contract. In his definition of human exchanges, Menninger focused simultaneously on the written and non-verbalised contract between the patient and the psychotherapist. However, the first researcher to officially use the term "psychological contract" was Argyris (1960), who attempted to cast light on the unwritten expectations and obligations arising between employees and the employer, going beyond formal legal arrangements. In his research, Argyris made an interesting observation that both the employer and the employee sometimes purposefully ignore unacceptable behaviour of the other party in order to maintain effective continuity of the contract (Argyris 1960). Other theorists such as Levin- 
son, Price, Munden, Mandl and Solley (1962) and Schein $(1965 ; 1980)$ are also among the early contributors to the theory of psychological contract.

The main idea behind the concept developed by Levin son et al. (1962) was that human needs lead to the initiation and development of relationships where each party behaves in such a way as to meet the needs of the other party. The expectations arising from this exchange lay the foundation of the psychological contract. Most likely, the emphasis on individual needs changed the further conceptualisation of the psychological contract. According to this approach, as long as the organisation meets its employees' needs, employees feel obliged to reciprocate, and strive to meet the needs of the organisation. Therefore, needs are very closely linked to obligations, and the latter are considered to be the essence of the psychological contract by authors such as Levinson et al. (1962).

Schein presented his approach to the psychological contract based on Argyris' theory of organisation. According to Schein, the notion of psychological contract means that an individual has multiple expectations towards the organisation and that the organisation formulates expectations towards its employees (Schein 1965). These expectations may relate to different areas: 1) economic issues (e.g. compensation, bonuses), 2) organisational solutions (e.g. the option to work from home for some of the time), and 3) psychological aspects (e.g. risk of occupational stress, sense of belonging or social respect), but the essence of the psychological contract mainly lies in the expectations related to intangible, psychological aspects of work. In his later works, Schein (1980) writes that the psychological contract draws attention to the understanding and management of behaviour in organisations. According to this author, expectations do not have to be written down or even clearly articulated in order to determine behaviour. One example can be the employer's expectation that employees will guard the corporate reputation while employees will expect a reward for an idea that increases efficiency in a particular area of organisational activities.

One of the earliest examples of empirical work on matching the mutual expectations and commitments of both parties to the contract is Kotter's theory (1973). In the matching theory, the psychological contract is understood as an indirect contract that regulates mutual relations by generating expectations that constitute an obligation to take specific actions (Kotter 1973). In this case, matching refers mainly to the similarity of expectations of both parties in terms of what they should receive and do for each other (i.e. matching at the level of their mutual relationship). The individual perception of matching among the employees is neglected (i.e. how individuals perceive the matching). Although there are several other examples of similar research (cf. Roehling 1996), Kotter's matching theory made a significant contribution to the early conceptualisation of psychological contract. 


\section{The theory of psychological contract as a new research perspective}

The concept of a psychological contract was first used in the early 1960s in the works of Levinson and his collaborators (1962) and Schein (1965). Briner and Conway (2005) claim that the new wave of literature on the psychological contract began in the 1980s with Rousseau (1989), which fundamentally changed further development of the theory (Freese, Schalk 2008). Cullinane and Dundon (2006) describe the impact of this study as an initiated revival or renaissance of the psychological contract. Table 1 presents the chronological context of the most significant definitions of psychological contract as a concept.

Table 1. The historical development of the definition of "psychological contract"

\begin{tabular}{|c|c|}
\hline Theorists & Early definitions of psychological contract \\
\hline 1 & 2 \\
\hline Argyris (1960: 96) & $\begin{array}{l}\text { "A psychological contract is an implicit obligation of the par- } \\
\text { ties (foremen and employee) to respect each other's standards } \\
\text { of employment and working conditions. Employees are com- } \\
\text { mitted to maintaining high productivity and the foremen is } \\
\text { to take care of things that are important to the employees, } \\
\text { e.g. ensure freedom of action, ensure stability of employment } \\
\text { and adequate earnings". }\end{array}$ \\
\hline Levinson et al. (1962: 21) & $\begin{array}{l}\text { "[...] an effect of mutual expectations, hidden and non-verbal- } \\
\text { ised, that define the relationship between an individual and an } \\
\text { organisation. With this framework, it became clear that reci- } \\
\text { procity can be understood as a way in which a contract is con- } \\
\text { firmed, altered or denied overnight on the basis of the profes- } \\
\text { sional experience acquired within the organisation". }\end{array}$ \\
\hline Schein $(1965: 11,64-65)$ & $\begin{array}{l}\text { "The concept of a psychological contract means that a person } \\
\text { has multiple expectations towards the organisation and that } \\
\text { the organisation formulates expectations towards its employ- } \\
\text { ees. Expectations can relate to the entire pattern of rights, } \\
\text { privileges and duties between an employee and the organisa- } \\
\text { tion. [...] Whether a person actually acts, generates commit- } \\
\text { ment, loyalty and enthusiasm for the organisation's goals and } \\
\text { whether the person achieves satisfaction with his/her work } \\
\text { depends largely on two conditions: } 1 \text {. the degree to which the } \\
\text { organisation meets its own expectations, } 2 \text {. the subject-mat- } \\
\text { ter of the exchange: money offered in exchange for working } \\
\text { time; the need for social satisfaction in exchange for loyalty; } \\
\text { respect in exchange for belonging to the organisation [...]". }\end{array}$ \\
\hline Kotter (1973: 92) & $\begin{array}{l}\text { "The psychological contract is an implicit contract between an } \\
\text { individual and his organization which specifies what each ex- } \\
\text { pect to give and receive from each other in their relationship". }\end{array}$ \\
\hline
\end{tabular}


Table 1. (cont.)

\begin{tabular}{|c|c|}
\hline 1 & 2 \\
\hline Dunahee, Wangler (1974: 519) & $\begin{array}{l}\text { "[...] a psychological agreement between the two parties that } \\
\text { binds each employee and employer together". }\end{array}$ \\
\hline Portwood, Miller (1976: 109) & $\begin{array}{l}\text { "A psychological contract is defined as an implied agree- } \\
\text { ment, negotiated between the employee and the employing } \\
\text { company (usually when the employee enters the organisa- } \\
\text { tion). It involves mutual recognition of obligations to be ful- } \\
\text { filled by both parties in the course of their relationship". }\end{array}$ \\
\hline Schein (1980: 22) & $\begin{array}{l}\text { "The concept of a psychological contract assumes that there } \\
\text { is an unwritten set of expectations that operates at all times } \\
\text { between each member of the organisation and various man- } \\
\text { agers and other employees in the organisation". }\end{array}$ \\
\hline Theorists & Reconceptualisation of psychological contract \\
\hline Rousseau (1989: 123) & $\begin{array}{l}\text { "The term psychological contract refers to an individual's } \\
\text { beliefs regarding the terms and conditions of a reciprocal } \\
\text { exchange agreement between that focal person and another } \\
\text { party. Key issues here include the belief that a promise has } \\
\text { been made and a consideration offered in exchange for it, } \\
\text { binding the parties to some set of reciprocal obligations". }\end{array}$ \\
\hline $\begin{array}{l}\text { Robinson, Kraatz, Rousseau } \\
\text { (1994: 138) }\end{array}$ & $\begin{array}{l}\text { "A psychological contract consists of sets or private beliefs } \\
\text { about the perception of mutual obligations". }\end{array}$ \\
\hline Rousseau, Greller (1994: 386) & $\begin{array}{l}\text { "A psychological contract consists of a person's belief sys- } \\
\text { tem, shaped by the organisation, concerning the conditions of } \\
\text { exchange between the employee and the organisation". }\end{array}$ \\
\hline Rousseau (1995: 9) & $\begin{array}{l}\text { "[...] individual beliefs shaped by the organisation about the } \\
\text { agreed terms of exchange between an individual and the } \\
\text { organisation. A psychological contract in an organisation is } \\
\text { a commitment to act, based on a belief about mutual obliga- } \\
\text { tions that have been undertaken by two or more parties". }\end{array}$ \\
\hline Roehling (1996: 202) & $\begin{array}{l}\text { "At a general level, the term »psychological contract« is used } \\
\text { to refer to a set of beliefs about what employees offer to their } \\
\text { employer and what they receive in return". }\end{array}$ \\
\hline Herriot, Pemberton (1997: 45) & $\begin{array}{l}\text { "[...] the result of both parties' perception of their mutual re- } \\
\text { lationship and the offers made to each other. The psychologi- } \\
\text { cal contract is a social process through which this perception } \\
\text { is acquired". }\end{array}$ \\
\hline $\begin{array}{l}\text { Anderson, Schalk } \\
\text { (1998: 637) }\end{array}$ & $\begin{array}{l}\text { "Most employees [...] develop a positive and lasting psy- } \\
\text { chological bond with the organisation, based on an individu- } \\
\text { alised pattern of expectations about what the organisation } \\
\text { should offer and what it is obliged to do for its employees } \\
{[\ldots] . \text { In the relationship between the employer and the em- }} \\
\text { ployee, mutual obligations are partly defined in the formal } \\
\text { employment contract but for the most part they remain covert } \\
\text { and rarely discussed". }\end{array}$ \\
\hline
\end{tabular}




\begin{tabular}{|c|c|}
\hline 1 & 2 \\
\hline $\begin{array}{l}\text { McLean Parks, Kidder, } \\
\text { Gallagher (1998: 698) }\end{array}$ & $\begin{array}{l}\text { "A psychological contract is an idiosyncratic set of mutual } \\
\text { expectations that employees have in terms of their duties (i.e. } \\
\text { what they will do for the employer) and their rights (i.e. what } \\
\text { they expect in return)". }\end{array}$ \\
\hline Rousseau (1998: 665-666) & $\begin{array}{l}\text { "By definition, a psychological contract is seen as an ex- } \\
\text { change contract between two persons [Argyris 1962; } \\
\text { Levinson 1962; Rousseau 1989; Rousseau 1995]. The } \\
\text { perception of reciprocity is a key component of the psycho- } \\
\text { logical contract". }\end{array}$ \\
\hline Sparrow (1998: 30-63) & $\begin{array}{l}\text { "[...] a psychological contract is defined as a set of expecta- } \\
\text { tions held by an employee, which defines what the person } \\
\text { and organisation expect, give and receive to maintain the } \\
\text { employment relationship [Rousseau 1990]. Contracts are } \\
\text { open-ended agreements that address the social and emotional } \\
\text { aspects of the employer-employee exchange. They represent } \\
\text { a set of unwritten mutual expectations". }\end{array}$ \\
\hline Rousseau (2001: 511-541) & $\begin{array}{l}\text { "[...] the psychological contract involves subjective beliefs } \\
\text { about the agreement on exchange between an individual and } \\
\text { an organisation [Rousseau 1995]. The contract is based on } \\
\text { promises and, over time, it takes the form of a mental model } \\
\text { or pattern which, like most other patterns, is relatively stable } \\
\text { and robust. The main feature of psychological contracts is } \\
\text { that a person is convinced that there is a common understand- } \\
\text { ing that obligates the parties involved to a particular way of } \\
\text { acting". }\end{array}$ \\
\hline $\begin{array}{l}\text { Makin, Cooper, Cox } \\
(2000: 33)\end{array}$ & $\begin{array}{l}\text { "A psychological contract is a set of people's beliefs about } \\
\text { the terms and conditions for implementing arrangements, } \\
\text { commitments and promises with regard to work and the re- } \\
\text { sulting benefits, both for the employer and the employee". }\end{array}$ \\
\hline Guest (2004: 541-555) & $\begin{array}{l}\text { "[...] perception of both parties to the employment relation- } \\
\text { ship - organisations and individual employees - as the result- } \\
\text { ing implied mutual promises and commitments". }\end{array}$ \\
\hline $\begin{array}{l}\text { Meckler, Drake, Levinson } \\
(2003: 218)\end{array}$ & $\begin{array}{l}\text { "A psychological contract is an agreement between the man- } \\
\text { agement and employees to meet mutual needs. As long as } \\
\text { the needs remain rationally met, the employee has a natural } \\
\text { motivation to work while meeting the requirements of the } \\
\text { company. In return for having these psychological needs met, } \\
\text { the employee makes an effort to perform productive work } \\
\text { that benefits the company". }\end{array}$ \\
\hline $\begin{array}{l}\text { Purvis, Cropley } \\
(2003: 213-241)\end{array}$ & $\begin{array}{l}\text { "The psychological contract consists of a discussion of the } \\
\text { following factors: reciprocity, relational reciprocities vis-à- } \\
\text { vis the individual/subjective perspective". }\end{array}$ \\
\hline
\end{tabular}


Table 1. (cont.)

\begin{tabular}{|c|c|}
\hline 1 & 2 \\
\hline $\begin{array}{l}\text { de Vos, Buyens, Schalk } \\
\text { (2003: 537-538) }\end{array}$ & $\begin{array}{l}\text { "A person's beliefs as to how to fulfil the terms of an ex- } \\
\text { change agreement with an organisation". }\end{array}$ \\
\hline Rousseau (2004: 120) & $\begin{array}{l}\text { "Beliefs, based on explicit or implicit promises about an } \\
\text { agreement on the terms and conditions of exchange between } \\
\text { an individual and an organisation, and the resulting benefits } \\
\text { to employees and the employer". }\end{array}$ \\
\hline Dabos, Rousseau (2004: 52-72) & $\begin{array}{l}\text { "[...] refers to a system of beliefs that the person and his or } \\
\text { her employer will keep the mutual contractual obligations". }\end{array}$ \\
\hline Schalk $(2005: 228,306)$ & $\begin{array}{l}\text { "[...] refers rather to the contractual relationship as such, but } \\
\text { also influences the shape of the psychological contract }[\ldots] " .\end{array}$ \\
\hline Guest (2007: 133) & $\begin{array}{l}\text { "The concept of a psychological contract refers to different as- } \\
\text { pects of employee relations within an organisation, and in par- } \\
\text { ticular to the changes they undergo and the consequences of } \\
\text { accepting and fulfilling mutual obligations in the form of com- } \\
\text { mitment to the organisation's objectives or staff fluctuations". }\end{array}$ \\
\hline Freese (2007) & $\begin{array}{l}\text { "A psychological contract is the employee's perception of } \\
\text { mutual obligations in the context of the relationship with } \\
\text { the organisation that shapes the relationship and regulates the } \\
\text { employee's behaviour". }\end{array}$ \\
\hline Schalk, Roe (2007: 167-182) & $\begin{array}{l}\text { "A psychological contract is the perception of mutual obliga- } \\
\text { tions". }\end{array}$ \\
\hline Venter, Levy (2011) & $\begin{array}{l}\text { "The psychological contract involves different parties, } \\
\text { structures and regulations. The contract covers both the } \\
\text { immediate working environment, the so-called »micro-en- } \\
\text { vironment « and, in a broader sense, the society, or »macro- } \\
\text { environment«". }\end{array}$ \\
\hline $\begin{array}{l}\text { De Cuyper, Schreurs, } \\
\text { Vander, Baillien, De Witte } \\
(2014: 1-10)\end{array}$ & $\begin{array}{l}\text { "[...] an individual's belief about the conditions of a mutual } \\
\text { exchange agreement between that individual and another } \\
\text { party. It emerges when an individual believes that a promise } \\
\text { has been made, such as a promise of continued employment, } \\
\text { in response to which the other party has made a particular } \\
\text { effort, such as diligent work, which constitutes an exchange } \\
\text { and a commitment to deliver further mutual benefits in the } \\
\text { future. Subjectivity is a key element in this approach: each } \\
\text { party to a psychological contract believes that both parties } \\
\text { have agreed to certain (the same) terms of the exchange, } \\
\text { which in fact will not always be true, since the understand- } \\
\text { ing of these arrangements may be different. When one party } \\
\text { thinks that the other one has not fulfilled its obligations, we } \\
\text { are dealing with a breach of contract". }\end{array}$ \\
\hline
\end{tabular}




\begin{tabular}{|l|l|}
\hline \multicolumn{1}{|c|}{1} & \multicolumn{1}{|c|}{2} \\
\hline $\begin{array}{l}\text { Rogozińska-Pawełczyk } \\
(2012: 63-76 ; 2016)\end{array}$ & $\begin{array}{l}\text { "[...] the psychological contract is considered in the perspec- } \\
\text { tive of the mutual perception of the exchange relationship and } \\
\text { means that the behaviour of the employee and the superior } \\
\text { is best understood as a dynamic process, subject to constant } \\
\text { change. The expectations and offers formulated by both the } \\
\text { superior and the employee may be subject to change. During } \\
\text { the employment relationship the scope of the psychological } \\
\text { contract will change, and the mutual, subjective expectations } \\
\text { and commitments will cover a somewhat different part of the } \\
\text { employee-employer relationship. As a result of changes, the } \\
\text { internal balance of the psychological contract may be upset". }\end{array}$ \\
\hline
\end{tabular}

Source: Author's own analysis.

The primary purpose of the psychological contract, as understood by Rousseau (1989), is to understand and explain norms of behaviour under the employment relationship. This approach focuses on the relationships of individual employees, each of whom enters into unwritten contracts with the organisation. According to Rousseau, the psychological contract defines, on the one hand, how the employee constructs a long-term perspective of job security and, on the other hand, how the employer strives to ensure employee involvement in the fulfilment of organisational interests. This definition indicates that social exchange becomes the essential component of a psychological contract and it consists not only of individual expectations but also promises of mutual obligations. This theory shows what kind of values employees appreciate and what motivates them. Therefore, it is important to find a formula for mutual relations and actions to ensure that the expectations of both the employer and the employee can be met.

Rousseau (1989) built a framework for understanding the psychological contract known to this day, but many of its dimensions are still being debated (Sutton, Griffin 2004; Thomas, Anderson 1998). Moreover, further exploration of this concept reveals more in-depth and more specific research areas of the concept, as well as the emergence of a critical approach to psychological contract (Arnold 1996: 511; Guest 1998; Briner, Conway 2005).

Schalk and Roe's research also emphasises that the psychological contract determines the shape of the relationship between an employee and an organisation, often complementing the formal arrangements (Schalk, Roe 2007). This entails the importance of the role of the contract, as it enables the employer to predict employees' behaviour and to use relevant HR management methods and tools to influence work-related attitudes, which helps the organisation to achieve its goals. Researchers look at how the content of the contract evolves, how employees' expectations and commitments change over time, and when employees begin to see that the informal contract has been breached. 
As a theoretical concept, the psychological contract provides an opportunity to explore employee relations (Guest 2004; 2011), which can be renegotiated and modified over time to help to establish and maintain the formal and informal contracts between the employee and the employer. In Guest's analytical model applied to the psychological contract, changes in the relationship between the employee and the employer are viewed in the dynamic context of work and organisational conditions (Guest 2011). This approach finds a follow-up in Rogozińska-Pawełczyk's definition (2016), which emphasises the dynamics of the contract, i.e. naturally occurring changes in the status and content of the psychological contract over time, affecting the performance of the organisation since they determine the employees' attitudes towards work and their behaviour in relation to it.

Research on the psychological contract conducted after 2000 indicates that it is sometimes viewed as "loyalty in exchange for security" (Bańka et al. 2002: 33). In their definition of the psychological contract, Fantinato and Casado (2011) emphasise employee loyalty in exchange for job security. This mutual exchange is mainly based on hierarchical relations, where the top managers are responsible for employee welfare (Fantinato, Casado 2011).

The aforementioned definitions clearly indicate that while there are similarities in the understanding of the psychological contract, there is evident variation regarding the different constituent components of the concept. For instance, Herriot and Pemberton (1997) consider the psychological contract as consisting of two perspectives: that of the employee and that of the organisation, while Rousseau (1995), Morrison and Robinson (1997) believe that it is only the employees and not the organisation that can enter into, and perform, psychological contracts.

The findings regarding the definitions of psychological contract differ significantly vis-à-vis previous and contemporary research in four main areas:

1) Unlike earlier studies, which stressed the role of mutual expectations, those conducted after 1989 put a greater emphasis on the nature of psychological contracts. In this perspective, the contract mainly involves expectations, promises and mutual obligations (Guest 1998), giving rise to the anticipation of events (Purvis, Cropley 2003) and shaping attitudes and emotions that influence organisational behaviour.

2) A departure from looking at the psychological contract from the perspective of two parties, towards seeing it as an individual phenomenon existing at the subjective level. Previous approaches emphasised the nature of understanding between the two parties, whereas contemporary ideas focus largely on employees' individual perceptions that influence their feelings, attitudes and behaviours.

3) Previous theoretical discourse identified essential human needs as a driving force that shapes expectations. In contrast, the contemporary discourse sug- 
gests that the structure of the psychological contract is based either on an individual perception of one's own and organisational behaviour in terms of unequivocal oral or written promises, or presumed promises arising from consistent, repetitive patterns of behaviour demonstrated by both parties.

4) Earlier explications tended to focus on the extent to which employees perceived the match between the gratuities offered by the organisation and the efforts made by employees, regardless of what was promised. Contemporary approaches to the nature of the psychological contract introduce the idea of contract breach or violation as the main mechanism that links the psychological contract to organisational and individual performance. The existing reflection also implies that a breach of contract will generate more intense reactions than unfulfilled expectations, as it triggers anger, a sense of betrayal, and reluctance, which can dampen motivation, undermine job satisfaction and lead to a desire to leave the organisation (Turnley et al. 2003; Behery et al. 2016).

\section{Conclusion}

The main aim of this article was to offer a chronological review of the definition of psychological contract, to identify the range of definitions offered by scholars, and to analyse the evolution of this concept. Many concepts are characterised by multiple definitions and are understood and employed by researchers in a variety of ways. Sometimes definitions constructed by different researchers at different times are very similar. In other cases, the same notion is conceptualised in very different ways. Moreover, there are situations where the definitions are so different that they may mislead lay readers or novice researchers. For this reason, the discussion has been limited only to key concepts and functions included in the definition of a psychological contract.

The literature review has shown that researchers have been very interested in the concept of psychological contract that shapes the employment relationship between an employee and an employer (Dulac et al. 2008; Suazo, Turnley 2010). Nowadays, scholars perceive the psychological contract as a framework that explains employment relations (Rogozińska-Pawełczyk 2012; 2016) and helps them to predict and understand employees' attitudes and behaviour (cf. Braekkan 2012).

When tracing the history and evolution of the concept of psychological contract, it was noticed that it can be divided into two key periods. The first one covers the early history of the psychological contract initiated by Argyris (1960), explaining the possible ways in which the mutual obligations and expectations of the two parties of the employment relationship are perceived. The early definitions consisted of descriptions of how the two parties to employment relationship, i.e. the employee and the employer, can perceive mutual obligations and expecta- 
tions. The problem of the anthropomorphisation of organisations was observed; they were viewed as entities capable of perceiving and sensing possible breaches or violations of contract by the other party to the relationship. This period is characterised by occasional theoretical development of the concept of psychological contract with little involvement of various disciplines and sub-disciplines.

The second period begins with the emergence of Rousseau's ground-breaking concept (1989), stressing the subjectivity of the psychological contract in that it includes "the term psychological contract refers to an individual's beliefs regarding the terms and conditions of a reciprocal exchange agreement between that focal person and another party. Key issues here include the belief that a promise has been made and a consideration offered in exchange for it, binding the parties to some set of reciprocal obligations"; "the individual beliefs of the employee shaped by the organisation regarding the rules of mutual exchange" (Rousseau 1995). This period is characterised by a detailed theoretical analysis relating to an employee's individual beliefs about the requirements imposed on them, and employee's expectations towards the employer. The new definition of the psychological contract created an impulse to develop an interface with various disciplines, i.e. sociology, psychology, or management sciences.

Although the views and meanings of the concept of psychological contract have changed over time, discourse on the subject still continues (Kelley-Patterson, George 2002; Linde 2015). Ultimately, it can be concluded that the various definitional issues discussed in this article are fundamental to the whole range of research in the social sciences and management sciences. The main argument in favour of employing the concept of psychological contract in these areas is that the psychological contract makes employees and organisations more productive. Employees who commit to something and intend to fulfil these commitments can anticipate things and make plans because their actions are better defined and more predictable, both for themselves and for others. When employees understand mutual commitments during their work, the degree of mutual predictability increases and becomes achievable. However, regardless of their foundation, mutual predictability is the strongest factor in coordinating effort and planning.

\section{Bibliography}

Anderson N.R., Schalk R. (1998), The psychological contract in retrospect and prospect, "Journal of Organizational Behavior", vol. 19(7), pp. 637-647.

Argyris C. (1960), Understanding Organisational Behavior, The Dorsey Press Inc., Homewood.

Arnold J. (1996), The psychological contract: a concept in need of closer scrutiny?, "European Journal of Work and Organisational Psychology", vol. 5(4), pp. 511-520.

Bańka A., Łącała Z., Noworol C., Ratajczak Z. (2002), University Management. Governance efficiency and efficacy of administration, Jagiellonian University, Kraków.

Barnard C.I. (1938), The Function of Executive, Harvard University Press, Cambridge. 
Behery M., Abdallah S., Parakandi M., Kukunuru S. (2016), Psychological contracts and intention to leave with mediation effect of organisational commitment and employee satisfaction at times of recession, "Review of International Business and Strategy", vol. 26(2), pp. 184-203.

Braekkan K.F. (2012), High performance work systems and psychological contract violations, "Journal of Managerial Issues", vol. 24(3), pp. 277-292.

Briner R.B., Conway N. (2005), Understanding Psychological Contracts at Work, Oxford University Press, New York.

Coyle-Shapiro J.A.-M., Shore L.M., Taylor S.M.S., Tetrick L.E. (2004), The Employment Relationship: Examining psychological and contextual perspectives, Oxford University Press, New York.

Cullinane N., Dundon T. (2006), The psychological contract: a critical review, "International Journal of Management Reviews", vol. 8(2), pp. 113-229.

Dabos G.E., Rousseau D.M. (2004), Mutuality and reciprocity in psychological contracts of employees and employers, "Journal of Applied Psychology", vol. 89, pp. 52-72.

De Cuyper N., Schreurs B.H.J., Vander Elst T., Baillien E., De Witte H. (2014), Exemplification and perceived job insecurity. Associations with self-rated performance and emotional exhaustion, "Journal of Personnel Psychology", vol. 13(1), pp. 1-10.

De Vos A., Buyens D., Schalk R. (2003), Psychological contract development during organizational socialization: adaptation to reality and the role of reciprocity, "Journal of Organizational Behavior", vol. 24(5), pp. 537-559.

Dulac T., Coyle-Shapiro J.A.-M., Henderson D.J., Wayne S.J. (2008), Not all responses to breach are the same: the interconnection of social exchange and psychological contract processes in organisations, "The Academy of Management Journal”, vol. 51(6), pp. 1079-1098.

Dunahee M.H., Wangler L.A. (1974), The psychological contract: a conceptual structure for management/employee relations, "Personnel Journal", vol. 53(7), pp. 518-526.

Freese C. (2007), Organizational Change and the Dynamics of Psychological Contracts: A longitudinal study, Ridderprint, Ridderkerk.

Freese C., Schalk R. (2008), How to measure the psychological contract? A critical criteria based review of measures, "South African Journal of Psychology", vol. 38(2), pp. 269-286.

Guest D. (1998), Is the psychological contract worth taking seriously?, "Journal of Organizational Behavior", vol. 19, pp. 649-664.

Guest D. (2004), The psychology of the employment relationship: an analysis based on the psychological contract, “Applied Psychology: An International Review”, vol. 53(4), pp. 541-555.

Guest D. (2007), HRM and the worker: towards a new psychological contract?, [in:] P. Boxall, J. Purcell, P.M. Wright (eds.), The Oxford Handbook of Human Resource Management, Oxford University Press, New York, pp. 128-146.

Guest D. (2011), Human resource management and performance: still searching for some answers, "Human Resource Management Journal", vol. 21, pp. 3-13.

Herriot P., Pemberton C. (1997), Facilitating new deals, "Human Resources Management Journal", vol. 7, pp. 45-56.

Hobbes T. (2005), Lewiatan, czyli materia, forma i władza państwa kościelnego i świeckiego, transl. C. Znamierowski, Fundacja Aletheia, Warszawa.

Kelley-Patterson D., George C. (2002), Mapping the contract: an exploration of the comparative expectations of graduate employees and human resource managers, "Journal of Services Research", vol. 2(1), pp. 55-74.

Kotter J.P. (1973), The psychological contract: managing the joining-up process, "California Management Review", vol. 15(3), pp. 91-99. 
Levinson H., Price C.R., Munden K.J., Mandl H.J., Solley C.M. (1962), Men, Management, and Mental Health, Harvard University Press, Cambridge.

Linde B. (2015), The Value of Wellness in the Workplace, Springer Briefs in Economics, NorthWest University, Potchefstroom, South Africa.

Locke J. (2002), Myśli o wychowaniu, transl. M. Heitzman, Wydawnictwo Akademickie Żak, Warszawa.

Makin P., Cooper C., Cox C. (2000), Organizacje a kontrakt psychologiczny: zarzadzanie ludźmi w pracy, transl. G. Kranas, Wydawnictwo Naukowe PWN, Warszawa.

March J.G., Simon H.A. (1958), Organizations, John Wiley \& Sons, New York.

Meckler M., Drake B.H., Levinson H. (2003), Putting psychology back into psychological contracts, "Journal of Management Inquiry", vol. 12(3), pp. 217-228.

Menegon L.F., Casado T. (2011), Psychological contracts: a review of literature, "Revista de Administração", vol. 47, pp. 571-580.

Menninger K. (1958), Menninger Clinic Monograph Series. Theory of psychoanalytic technique, Basic Books, New York.

Morrison E.W., Robinson S.L. (1997), When employees feel betrayed: a model of how psychological contract violation develops, "The Academy of Management Review", vol. 22, no. 1, pp. 226-256.

Pate J. (2006), The changing contours of the psychological contract: unpacking context and circumstances of breach, "Journal of European Industrial Training", vol. 30(1), pp. 32-47.

Portwood J.D., Miller E.L. (1976), Evaluating the psychological contract: its implications for employee job satisfaction and work behavior, "Academy of Management Proceedings", no. 1, pp. 109-113.

Purvis L.J., Cropley M. (2003), The psychological contracts of National Health Service nurses, "Journal of Nursing Management", vol. 11(2), pp. 107-120.

Robinson S.L., Kraatz M.S., Rousseau D.M. (1994), Changing obligations and the psychological contract: a longitudinal study, "Academy of Management Journal”, vol. 37(1), pp. 137-152.

Roehling M.V. (1996), The origins and early development of the psychological contract construct, Academy of Management, Best Papers Proceedings, pp. 202-206.

Rogozińska-Pawełczyk A. (2011), From relational to transactional psychological contract - changing paradigm, "Human Resources Management", no. 3-4, pp. 61-77.

Rogozińska-Pawełczyk A. (2012), The role of comprehensive remuneration in shaping the psychological contract, "Human Resources Management", no. 5, pp. 63-76.

Rogozińska-Pawełczyk A. (2016), Human Resources Management based on a Psychological Contract, IPISS Publishing House, Warszawa.

Rousseau D.M. (1989), Psychological and implied contracts in organisations, "Employee Responsibilities and Rights Journal", vol. 2(2), pp. 121-140.

Rousseau D.M. (1990), New hire perceptions of their own and their employer's obligations: a study of psychological contracts, "Journal of Organizational Behavior", vol. 11(5), pp. 389-400.

Rousseau D.M. (1995), Psychological Contracts in Organisations: Understanding the written and unwritten agreements, Sage Publications, London.

Rousseau D.M. (1998), The "problem" of the psychological contract considered, "Journal of Organizational Behavior”, vol. 19, pp. 665-671.

Rousseau D.M. (2001), Schema, promise and mutuality: the building blocks of the psychological contract, "Journal of Occupational and Organizational Psychology", vol. 74(4), pp. 511-541.

Rousseau D.M. (2004), Psychological contracts in the workplace: understanding the ties that motivate, "The Academy of Management Perspectives", vol. 18(1), pp. 120-127. 
Rousseau D.M., Greller M.M. (1994), Human resource practices: administrative contract makers, "Human Resource Management", vol. 33(3), pp. 385-401.

Schalk R. (2005), Changes in the employment relationship across time, [in:] J.A.-M. Coyle-Shapiro, L.M. Shore, M.S. Taylor, L.E. Tetrick (eds.), The Employment Relationship. Examining psychological and contextual perspectives, Oxford University Press, New York, pp. 284-311.

Schalk R., Roe R.A. (2007), Towards a dynamic model of the psychological contract, "Journal for the Theory of Social Behaviour", vol. 37(2), pp. 167-182.

Schein E.H. (1965), Organisational Psychology, Prentice Hall, Englewood Cliffs-New York.

Schein E.H. (1980), Organisational Psychology, 3rd ed., Prentice Hall, Englewood Cliffs-New York.

Sparrow P.R. (1998), Reappraising psychological contracting, "International Studies of Management and Organization", vol. 28, no. 1, pp. 30-63.

Suazo M.M., Turnley W.H. (2010), Perceived organisational support as a mediator of the relations between individual differences and psychological contract breach, "Journal of Managerial Psychology", vol. 25(6), pp. 620-648.

Sutton G., Griffin M.A. (2004), Integrating expectations, experiences, and psychological contract violations: a longitudinal study of new professionals, "Journal of Occupational and Organisational Psychology", vol. 77(4), pp. 493-514.

Thomas H.D.C., Anderson N. (1998), Changes in newcomer's psychological contracts during organisational socialisation: a study of recruits entering the British Army, "Journal of Organizational Behaviour", vol. 19, pp. 745-767.

Turnley W.H., Bolino M.C., Lester S.W., Bloodgood J.M. (2003), The impact of psychological contract fulfilment on the performance of in-role and organisational citizenship behaviors, "Journal of Management", vol. 29(2), pp. 187-206.

Venter R., Levy A. (2011), Labour Relations in South Africa, 3rd ed., Oxford University Press, Cape Town.

Zagenczyk T.J., Gibney R., Kiewitz C., Restubog S.L.D. (2009), Mentors, supervisors and role models: do they reduce the effects of psychological contract breach?, "Human Resource Management Journal”, vol. 19(3), pp. 237-259.

\title{
UŻYTECZNOŚĆ KONCEPCJI KONTRAKTU PSYCHOLOGICZNEGO - ROZWAŻANIA DEFINICYJNE I KONCEPCYJNE
}

\begin{abstract}
Abstrakt. W niniejszej pracy rozważania skupiają się na dokonaniu przeglądu, analizy i syntezy literatury na temat kontraktu psychologicznego. Głównym celem syntezy obszernego przeglądu literatury przedmiotu jest wskazanie zakresu kreowania relacji interpersonalnych i stosunków zatrudnienia w organizacji. Artykuł wpisuje się w nurt teoretycznych rozważań zmierzających do poznania i wyjaśnienia podwalin oraz chronologicznej analizy rozwoju koncepcji kontraktu psychologicznego. Prześledzenie rozwoju pojęcia kontraktu psychologicznego jest jednym z głównych powodów bliższego poznania znaczenia kontraktu psychologicznego jako regulatora związków zatrudnienia pomiędzy pracodawcą a pracownikiem. Analiza i synteza uzyskanych ustaleń staje się przyczynkiem do określenia luki w prowadzonych dotychczas rozważaniach i wskazuje implikacje dla przyszłych badań. Jak dotąd ani w literaturze obcojęzycznej, ani tym bardziej w rodzimej nie podjęto kompleksowej próby chronologicznego usystematyzowania i uchwycenia zmian na przestrzeni lat w terminologii kontraktu psychologicznego.
\end{abstract}

Słowa kluczowe: kontrakt psychologiczny, relacje pracownik-pracodawca, wzajemne oczekiwania i zobowiązania. 